\title{
Research
}

\section{Measuring Household Resilience to Floods: a Case Study in the Vietnamese Mekong River Delta}

\author{
Kien V. Nguyen ${ }^{1,2}$ and Helen James ${ }^{2}$
}

\begin{abstract}
The flood is a well-known phenomenon in the Vietnamese Mekong River Delta (MRD). Although people have experienced the impact of floods for years, some adapt well, but others are vulnerable to floods. Resilience to floods is a useful concept to study the capacity of rural households to cope with, adapt to, and benefit from floods. Knowledge of the resilience of households to floods can help disaster risk managers to design policies for living with floods. Most researchers attempt to define the concept of resilience; very little research operationalizes it in the real context of "living with floods". We employ a subjective well-being approach to measure households' resilience to floods. Items that related to households' capacity to cope with, adapt to, and benefit from floods were developed using both a five-point Likert scale and dichotomous responses. A factor analysis using a standardized form of data was employed to identify underlying factors that explain different properties of households' resilience to floods. Three properties of households' resilience to floods were found: (1) households' confidence in securing food, income, health, and evacuation during floods and recovery after floods; (2) households' confidence in securing their homes not being affected by a large flood event such as the 2000 flood; (3) households' interests in learning and practicing new flood-based farming practices that are fully adapted to floods for improving household income during the flood season. The findings assist in designing adaptive measures to cope with future flooding in the MRD.
\end{abstract}

Key Words: impacts; floods; Mekong River Delta; resilience; vulnerability; well-being

\section{INTRODUCTION}

Floods are a familiar and frequent feature of life in the Vietnamese Mekong River Delta (MRD) (Socialist Republic of Vietnam 2004). Among disaster events, flood frequency, damage and mortality were ranked as the second most severe after the impacts of typhoons in Vietnam (Imamura and To 1997). Half of the MRD's total area (about 2.0 million ha) is annually flooded (Tuan et al. 2007). Floods bring fish, wash farm residuals, deposit silt sediment, purify water, kill pests, and wash alum, which makes the soil of the delta fertile (Tien 2001b; Tran et al. 2008). It is estimated that the average fish capture in the delta is about $500 \mathrm{~kg}$ per household per year, providing a significant protein source for local people (Mekong River Commission (MRC) 2002, Nguyen and Binh 2004). Every year, the flood deposits around 150 million tonnes of fertile sediment on paddy fields, so rice farmers achieve good yields after every flood season thanks to water and sediment brought by the flooding (Tien 2001b). Traditionally, people relied on floods for building their livelihoods in the flood prone region of the delta (Biggs et al. 2009). More recently, farmers can develop flood-based livelihoods to improve household income during several flood months (Nguyen 2008). However, some people are vulnerable, while some are resilient to flood events (Lebel et al. 2006).

The flood can be seen as an "external shock", if the flood is either too "big' or too "small", it exceeds the coping capacity of households. Local people distinguish between flooding that is "large", "moderate" and "small" (Tien 2001b). The flooding of 1998 was thought to have been the smallest flood in the past
80 years (Figure 1). A small flood often does not cause damage to property, houses, crops and other livelihood activities and assets, but it affects rural livelihoods in different ways. Poor people are more likely to lose their income from fishing activities as they cannot catch many fish due to low water. The large floods occurred in 1850, 1937, 1961, 1966, 1978, 1984, 1994, 1995, 1996, 2000, 2001, and 2002 (Can Tho University 1995, Socialist Republic of Vietnam 2004). The worst flood, in 2000, affected 11 million people living in 610 flooded communes, of which 4.5 million people lived in the 77 most affected subdistricts (communes) where flood levels exceeded more than 3 meters (Nguyen et al. 2003). In addition, more than 800,000 houses were inundated; 50,000 households had to be evacuated; 500,000 households needed emergency support; and 800,000 high school students had to stop their studies (Tien 2001a). About 55,123 ha of rice crop were completely destroyed and an additional 159,260 ha of rice were inundated and so had to be harvested immediately (Tinh and Hang 2003). The total direct economic cost of the 2000 flood was estimated at USD 289.8 million (1\$ VND 13,800 in 2000).

There is additional evidence that a rise in sea level due to climate change will increase the risk of flooding in the MRD, which will affect the livelihoods of millions of people (Wassmann et al. 2004, Dasgupta et al. 2007, Eastham et al. 2008, Reid 2008). Sea level is expected to increase by $75 \mathrm{~cm}$ by the end of the $21^{\text {st }}$ century in Vietnam's Mekong Delta (Ministry of Natural Resources and Environment 2009). Consequently, the livelihoods of people in the MRD will be

\footnotetext{
${ }^{1}$ An Giang University, Vietnam, ${ }^{2}$ Australian Demographic and Social Research Institute, Australian National University
} 
Fig. 1. The highest water levels during different flood years in the MRD (1929-2007). Source: Tuan et al. 2007.

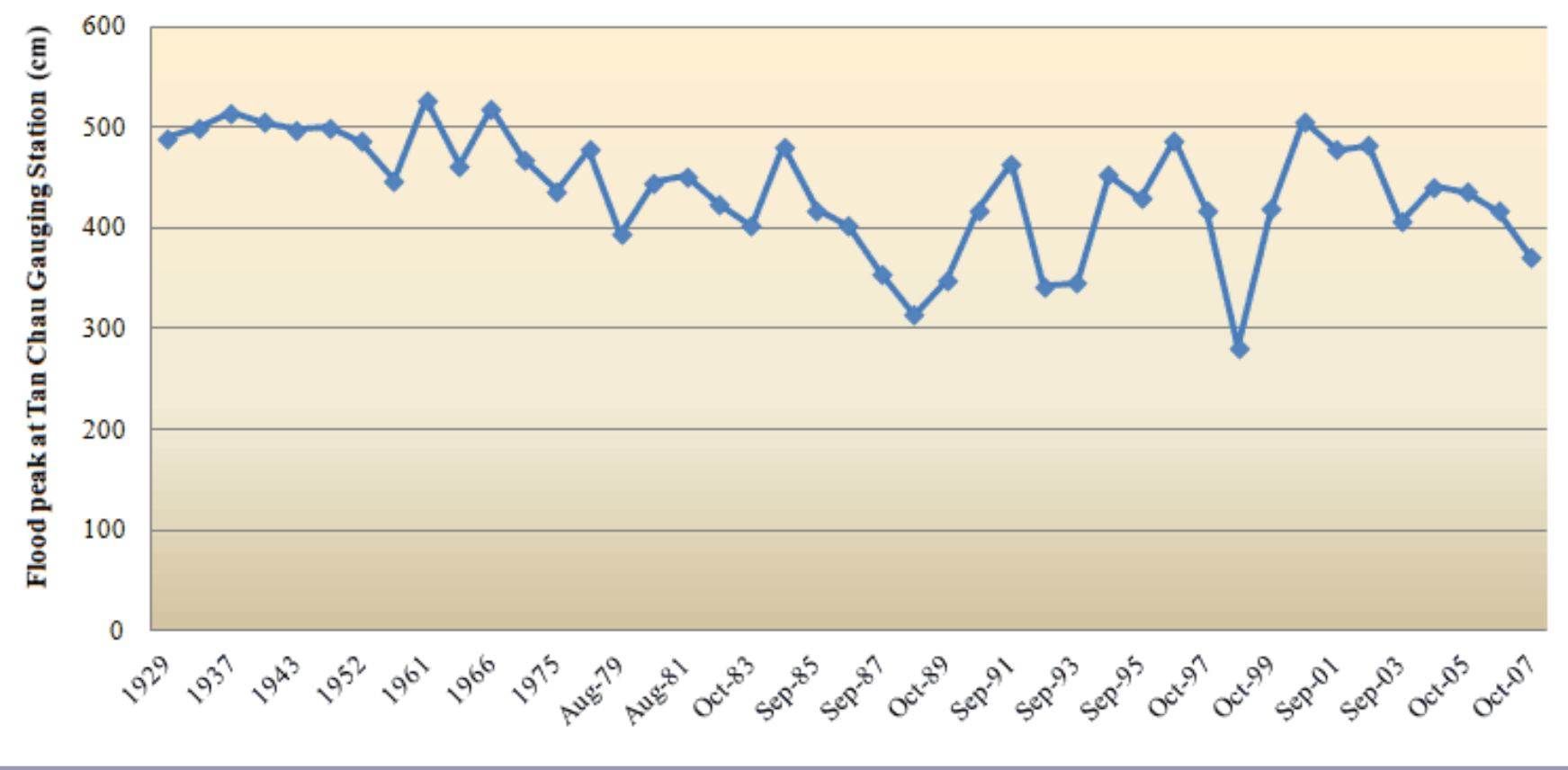

vulnerable if measures are not undertaken to cope with and adapt to future flooding.

Resilience has become a useful concept in the study of environmental hazards. The term "resilience" first originated from the ecological discipline. Holling (1973:17) defines resilience as "a measure of the ability of these systems to absorb change of state variables, driving variables and parameters and still persist". This concept focuses on the capacity of an ecological system to absorb changes but still maintain its core function. Flood risk managers define resilience as "the ability of the system to recover from floods" (Bruijn 2004:199). In a social system, Adger et al. (2002:358) define social resilience as "the ability of a system to absorb external changes and stress, while maintaining the sustainability of their livelihoods". A system in this context may be a region, a community, a household, an economic sector, a business, a population group, or an ecological system (Brooks 2003). Buckle (2006:91) refers to resilience as the "capacity to withstand loss". Norris et al. (2008:130) define resilience as "a process linking a set of adaptive capacities to a positive trajectory of functioning and adaptation after a disturbance". Recently, the concept of resilience has been seen in a linked social and ecological system (Folke et al. 1998, Adger 2000, Folke 2006). The resilience concept is concerned with the capacity for renewal, reorganization and development (Folke 2006); creativity (Adger 2000, Maguire and Hagan 2007), and transformation in a social-ecological system
(Walker et al. 2004) and capacity to maintain its identity (Cumming et al. 2005).

Although there are various definitions of resilience from different disciplines, three common properties of resilience dominate in resilience literature (Carpenter et al. 2001). The first property is about the speed of recovery at which a system can recover after disturbance. So natural hazard researchers attempt to observe the speed of recovery after disasters as a measure of resilience (Bruijn 2004). The second is the magnitude of a disturbance relative to a threshold that can be absorbed before a system changes its structure by changing the processes and variables that control it (Colding et al. 2003). The final property is about the capacity to learn from and to create new things from disturbance, and to transform (Folke et al. 2002, Berkes and Seixas 2005). Therefore, the conventional approach to measure resilience as the speed of recovery may not capture its full dimensions.

Resilience of the system is dependent on several factors such as demographic, social, cultural, economic, political, type of natural hazards, and geographical setting of the place (Gaillard 2007). However, these factors may vary at different levels of analysis (Buckle 2006). At the household level, access to agricultural land, diversity of income sources, and good housing quality create essential resources for households to cope with annual flood events in Bangladesh and climate change in the coastal province of Vietnam (Adger 1999, Brouwer et al. 2007). Learning to live with change and 
uncertainty, nurturing learning and adapting, and creating opportunities for self-organization were found as the important factors for enhancing household resilience in the Cambodian context (Marschke and Berkes 2006). Marshall and Marshall (2007) identified four perceived factors that contribute to conceptualizing resilience at the individual level: (1) perception of risk associated with change, (2) perception of ability to learn, plan and self-organize, (3) perception of the ability to cope, and (4) level of interest in changes in an Australian context.

At the community level, Norris et al. (2008) identified four primary sets of capacities that enhance community resilience, including economic development, social capital, information and communication, and community competence. Economic development refers to economic growth, stability of livelihoods, and equal distribution of resources within the population (Adger 1999). Social capital refers to networks of social supports, bonding within community, bridging between communities, and networking between communities and government bodies (Adger 2003, Pelling and High 2005, Mathbor 2007). Information and communication refer to the system and infrastructure for informing the public because people need accurate information about danger and behavioral options for them to act quickly. Community competence is about the capacity of the community to learn, work together flexibly, and solve problems creatively. These contributing factors should be measurable in the practical context.

Most researchers attempt to define the concept of resilience; very little research operationalizes it in practice. Cumming et al. (2005) note that resilience is a multidimensional concept, so it is difficult to operationalize in practice. Coping with this problem, they develop a "surrogate approach" as an indirect way of measuring resilience (Carpenter et al. 2005: 967). Marschke and Berkes (2006) adopted the surrogate approach to operationalize resilience from livelihood perspectives in rural Cambodian villages using a subjective well-being approach. However, Marschke and Berkes (2006) only explore the well-being of households and communities in a qualitative manner; they do not attempt to quantify resilience indicators at a household level. It is argued that well-being is what people think and feel about their life or subjective wellbeing (Copestake and Camfield 2009). The subjective wellbeing approach was widely accepted in poverty and livelihood studies in developing countries (Narayan et al. 2000). However, little is known about different dimensions of households' resilience to floods in a real "living with floods" context. Knowledge of the ability of households to cope with, adapt to, and benefit from floods reflects their resilience, but there is no study that operationalizes the concept in the MRD.

\section{METHODS}

Three communes (Phu Duc, Thanh My Tay, and Trung An) were selected for this study to represent different flood and socioeconomic conditions of the MRD (Figure 2). The socioeconomic conditions and livelihood activities of the three locations are represented in Table 1.

Fig. 2. The Mekong River Delta and location of the study sites. Source: Quang (editor) 2012.

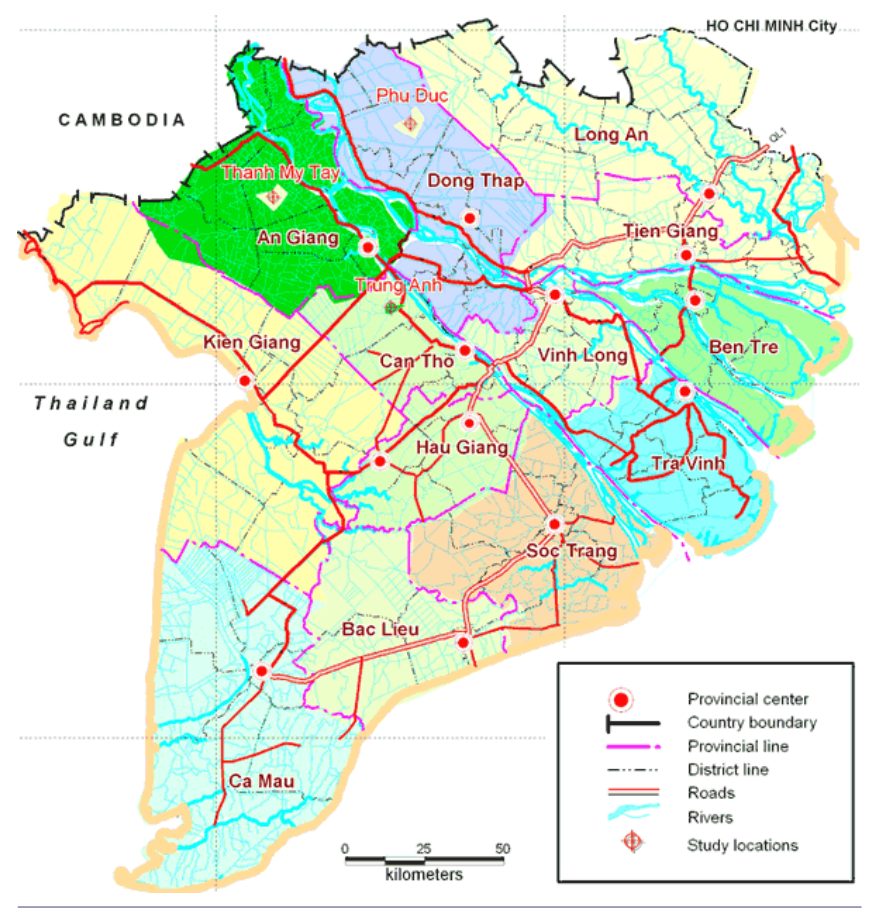

The study employed both qualitative and quantitative research approaches to conceptualize household resilience to floods. The three key qualitative data collection approaches for this study included in-depth interviews with key informants, focus group discussions (FGDs), and field observations. Four FGDs and some 10 in-depth interviews were carried out in each commune, each covering a range of social classes and gender. Information from the qualitative research was used for designing the structured questionnaires for the household survey in August 2010.

The study used a multiple items approach using both Likert scales and a dichotomous response to design questionnaires for measuring household resilience. As noted by de Vaus (2002) it is beneficial to use multiple indicators to measure the complexity of a concept. Multiple items also help to increase reliability and precision of the measure. The multiple item approach using Likert scales was widely accepted in measuring individual resilience to stresses in psychological disciplines (Wagnild and Young 1993, Connor and Davidson 2003, Yu and Zhang 2007, Baek et al. 2010, Wang et al. 2010), and individual resilience to institutional changes (Marshall and Marshall 2007). As rural households in the MRD have experienced the impacts of annual flood events for years, we 
Table 1. Socioeconomic conditions and livelihood activities in the three study sites

\begin{tabular}{|c|c|c|c|}
\hline \multirow{2}{*}{$\begin{array}{l}\text { Socioeconomic, demographic and flood } \\
\text { conditions }\end{array}$} & \multicolumn{3}{|c|}{ Selected sub-districts } \\
\hline & Phu Duc commune (site1) & $\begin{array}{r}\text { Thanh My Tay commune } \\
\text { (site2) }\end{array}$ & Trung An commune (site 3 ) \\
\hline Population (number of people) & 6,940 & 25,100 & 13,606 \\
\hline Population density (persons per sq km) & 212 & 637 & 194 \\
\hline Households & 1,586 & 5,141 & 2,362 \\
\hline Land area (ha) & 5,170 & 3,656 & 1,197 \\
\hline Poverty (\%) & 11.4 & 11.5 & 12.0 \\
\hline Flood depth & $>2.5 \mathrm{~m}$ (over 5 months) & $1.5-2.5 \mathrm{~m}$ (4-5 months) & $<1.5 \mathrm{~m}$ (<3 months) \\
\hline
\end{tabular}

argue that using a "subjective well-being approach" helps to identify the ability of households to cope with, adapt to, and benefit from floods.

Ten statements that reflect subjective well-being of rural households were developed to construct households' resilience to floods in the MRD. As reviewed in the introduction section, resilience is referred as the capacity of a system to cope with and recover from an external shock or stress. Some people may argue that flood events in the MRD are not external shocks because people have experienced the floods every year. However, we argue that large flood events such as the historic flood in 2000 can be seen as "external shocks" because they exceed the coping capacity of many people. Some people could cope well with the event, but many people were vulnerable to that flood. Therefore, the statements used in this approach to measure households' resilience to floods are related to their coping capacities in the 2000 flood event. The statements related to confidence in securing food, income, and health of family members during historic flood events (the 2000 flood), and safe evacuation in future extreme flood events due to climate change or rising sea levels, and recovery after the flood if they are affected; confidence in securing homes in a large flood event such as the 2000 historic flood, and their interest in learning and implementing new ways of living with floods (flood-based livelihoods). In this analysis, most of the items are more likely to focus on experiences or perceptions of households in coping with floods in the past rather than the capacity to cope with future flood events in the context of local climate change scenarios. Therefore, further studies should be carried out to incorporate possible changes in the flood regimes into measures of resilience.

The respondents, who represent their households, were asked to rate their agreement with 10 statements. The responses on the first nine items were provided using a five-point Likert scale, while a dichotomous response was applied for the last item (Table 2). The response rate was $100 \%$.

The stratified sampling approach was used to divide the total population of the delta into sub-populations of "three communes", based on the existing socioeconomic and natural flood characteristics of the delta. The samples were chosen on the basis of social groups: poor, medium-income and betteroff households. This approach has been widely used in rural development and natural hazard studies in developing countries (Smith et al. 2001, Tran et al. 2008). Within each stratum, five hamlets were randomly chosen and 30 households were randomly selected from the wealth ranking of households in each hamlet. In the case of Phu Duc commune, 50 samples were collected as there are only three hamlets in this commune. The total sample size in each case study was 150 . The exception was Thanh My Tay commune, for which there were 159 samples.

The average age of respondents was 52 years old. The proportion of male respondents was higher than that of female respondents. This may cause biases in terms of differences in perceptions between males and females toward floods. The education level of respondents and their family members was generally low. The average household size was 4.7. The gender ratio of households was equally distributed. Most respondents followed Hoa Hao Buddhism, while very few respondents belonged to the Cao Dai or Catholic religion. Poor households account for $39.4 \%$ of the sample, followed by well-off households $(31.8 \%)$ and medium-income households $(28.8 \%)$. Average household income was $\$ 2,918.0$ per year (\$1 or approx. VND 20,830.0 in 2010). However, the average income of poor households was $\$ 763$ per year. For mediumincome households it was $\$ 2,553.0$ per year, while better-off households had an average income of $\$ 5,909.0$ per year. The per capita income of each person was an average of $\$ 600.0$ per year. Per capita income in poor households was $\$ 168.0$ per year. In medium-income households, per capita income was $\$ 576.0$, and it was $\$ 1,161.0$ in better-off households.

A factor analysis was used for combining related variables into "composite" variables for conceptualizing components of household resilience to floods. Factor analysis helps us to identify patterns in responses to a set of questions (de Vaus 2002). The purpose of this technique is to reduce the large amount of variables to a smaller set of underlying variables 
Table 2. Statements for measuring household resilience to floods in the MRD

\begin{tabular}{|c|c|c|c|c|c|c|c|}
\hline Items & Statements $(\mathrm{N}=459)$ & Mean & $\begin{array}{l}\text { Strongly } \\
\text { Disagree }\end{array}$ & Disagree & $\begin{array}{l}\text { Do not } \\
\text { know } \\
\%\end{array}$ & Agree & $\begin{array}{c}\text { Strongly } \\
\text { Agree }\end{array}$ \\
\hline 1 & $\begin{array}{l}\text { I can replace my house quickly when it is } \\
\text { affected by floods }{ }^{\dagger} \text {. }\end{array}$ & 3.42 & 8.50 & 28.10 & 3.70 & 32.46 & 27.23 \\
\hline 2 & $\begin{array}{l}\text { I am confident that my house will not be } \\
\text { submerged by the highest floods in the last } \\
20 \text { years }{ }^{\dagger} \text {. }\end{array}$ & 3.54 & 8.06 & 23.53 & 4.79 & 31.37 & 32.24 \\
\hline 3 & $\begin{array}{l}\text { I am confident that my house will not } \\
\text { collapse or be swept away by the highest } \\
\text { floods in the last } 20 \text { years }{ }^{\dagger} \text {. }\end{array}$ & 3.31 & 11.55 & 25.93 & 4.79 & 32.68 & 25.05 \\
\hline 4 & $\begin{array}{l}\text { I am confident that my household has } \\
\text { enough rice to eat during the flood season }{ }^{\dagger} \text {. }\end{array}$ & 3.56 & 9.15 & 25.93 & 15.25 & 37.04 & 12.64 \\
\hline 5 & $\begin{array}{l}\text { I am confident that my household will not } \\
\text { need to borrow rice or money from } \\
\text { informal sources during the flood season }{ }^{\dagger} .\end{array}$ & 3.41 & 1.53 & 6.97 & 10.68 & 48.15 & 32.68 \\
\hline 6 & $\begin{array}{l}\text { I am confident that my household can find } \\
\text { a safe place to evacuate to if there is an } \\
\text { extreme flood event in the future }\end{array}$ & 3.18 & 1.74 & 12.20 & 13.73 & 54.03 & 18.30 \\
\hline 7 & $\begin{array}{l}\text { I am confident that children and elderly } \\
\text { people are safe during extreme floods }{ }^{\dagger} \text {. }\end{array}$ & 4.03 & 10.46 & 24.40 & 4.36 & 22.22 & 38.56 \\
\hline 8 & $\begin{array}{l}\text { I am confident that the health of my family } \\
\text { members will not be negatively affected by } \\
\text { floods }{ }^{\dagger} \text {. }\end{array}$ & 3.75 & 13.51 & 25.93 & 6.75 & 23.53 & 30.28 \\
\hline 9 & $\begin{array}{l}\text { I want to learn new farming practices to } \\
\text { cope with floods, such as fishing, prawn } \\
\text { farming }{ }^{\dagger} \text {. }\end{array}$ & 2.94 & 13.07 & 40.74 & 1.09 & 29.41 & 15.69 \\
\hline 10 & I have used new farming practices to cope & 0.23 & \multirow{2}{*}{\multicolumn{2}{|c|}{ Agree }} & \multirow{2}{*}{\multicolumn{3}{|c|}{ Disagree }} \\
\hline & & & & 27.7 & & & \\
\hline
\end{tabular}

${ }^{\dagger}$ Statements were measured using a 5-point scale for the first nine items: 1-strongly disagree, 2-disagree, 3- neither agree nor disagree, 4- agree, 5 - strongly agree. ${ }^{\ddagger}$ Statement was measured according to the binary response (0- No; 1 -Yes) for the ten items.

by creating factors (Kim and Mueller 1978). The principal component factor method is used in this analysis. There are a number of methods involving rotation variables including the quartimax method, the equamax method, and the varimax method (Kim and Mueller 1978). One of the most frequently used methods is the varimax method, which aims to minimize the number of variables that have a high loading on a factor. This approach was widely used when identifying the factors of the vulnerability analysis (Cutter et al. 2003, Fekete 2009). Because binary variables were not suitable for a factor analysis, each item response was standardized (z-score) before conducting a factor analysis using SPSS software. This method was used by identifying underlying factors in measuring social vulnerability to natural hazards (Cutter et al. 2003). Factors will be selected if they have an Eigenvalue greater than one. The results of factor analysis from SPSS were also triangulated by using MPLUS software with the original nonstandardized data.

\section{RESULTS}

\section{Definition of resilience to floods}

Results from factor analysis indicate that nine of ten statements reliably contribute to the scale, and formed the basis for measuring household resilience to floods (Table 3). The factor analysis in SPSS shows that the responses to the statements were best described by three factors that represent three components of resilience. The finding from the factor analysis conducted in MPLUS showed similar results, including three factors comprising nine items. These total factors in SPSS represented $68.0 \%$ of the variance. The first component represents $37.1 \%$ of the variance, including five statements $(1,4,5,6,8)$ relating to securing food, income, health, safe 
Table 3. Factor matrix of household resilience, Mekong River Delta, Vietnam, 2010 (nine standardized items)

\begin{tabular}{|c|c|c|c|c|c|}
\hline \multirow[t]{2}{*}{ Items } & \multirow[t]{2}{*}{ Statements } & \multicolumn{3}{|c|}{ Factor loadings } & \multirow{2}{*}{ Communality } \\
\hline & & Factor 1 & Factor 2 & Factor 3 & \\
\hline 1 & $\begin{array}{l}\text { I can replace my house quickly when it is affected by } \\
\text { floods }{ }^{\dagger} \text {. }\end{array}$ & 0.71 & & & 0.58 \\
\hline 4 & $\begin{array}{l}\text { I am confident that my household has enough rice to } \\
\text { eat during the flood season }{ }^{\dagger} \text {. }\end{array}$ & 0.90 & & & 0.83 \\
\hline 5 & $\begin{array}{l}\text { I am confident that my household will not need to } \\
\text { borrow rice or money from informal sources during } \\
\text { the flood season }{ }^{\dagger} \text {. }\end{array}$ & 0.88 & & & 0.80 \\
\hline 6 & $\begin{array}{l}\text { I am confident that my household can find a safe } \\
\text { place to evacuate to if there is an extreme flood event } \\
\text { in the future }{ }^{\dagger} \text {. }\end{array}$ & 0.41 & & & 0.22 \\
\hline 8 & $\begin{array}{l}\text { I am confident that the health of my family members } \\
\text { will not be negatively affected by floods }{ }^{\dagger} \text {. }\end{array}$ & 0.59 & & & 0.39 \\
\hline 2 & $\begin{array}{l}\text { I am confident that my house will not be submerged } \\
\text { by the highest floods in the last } 20 \text { years }{ }^{\dagger} \text {. }\end{array}$ & & 0.92 & & 0.90 \\
\hline 3 & $\begin{array}{l}\text { I am confident that my house will not collapse or be } \\
\text { swept away by the highest floods in the last } 20 \\
\text { years }^{\dagger} \text {. }\end{array}$ & & 0.92 & & 0.89 \\
\hline 9 & $\begin{array}{l}\text { I want to learn new farming practices to cope with } \\
\text { floods, such as fishing, prawn farming }{ }^{\dagger} \text {. }\end{array}$ & & & 0.86 & 0.75 \\
\hline \multirow[t]{3}{*}{10} & $\begin{array}{l}\text { I have used new farming practices to cope with } \\
\text { floods, such as fishing, prawn farming }\end{array}$ & & & 0.84 & 0.71 \\
\hline & Eigenvalues & 3.34 & 1.58 & 1.19 & 6.12 \\
\hline & $\%$ of variance & 37.14 & 17.55 & 13.32 & 68.01 \\
\hline
\end{tabular}

${ }^{\dagger}$ Statements were measured using a 5-point scale for the first nine items: 1-strongly disagree, 2-disagree, 3- neither agree nor disagree, 4- agree, 5- strongly agree. ${ }^{*}$ Statements were measured on a binary scale (0-No, 1-Yes). All items were standardized into $\mathrm{z}$-scores $(0,1)$. Selected factors have Eigenvalues greater than 1 . Selected variables have factor loadings greater than 0.3 Total variance is 68 .

evacuation during the flood season, and recovery after floods. The second component, representing $17.5 \%$ of the variance, consisted of two statements ( 2 and 3 ) related to the level of confidence of households that their houses will not be affected (submerged or collapsed) by future floods as large as the threshold flood of 2000 . The third component representing $13.3 \%$ of variance was comprised of two statements (9 and 10) related to the level of interest in learning and conducting new flood-based farming practices for living with floods. Reliability analysis shows that Cronbach's alpha coefficient of factor one is 0.77 ; factor two is 0.89 ; and factor three is 0.67 .

\section{Interpretation of resilience components}

Confidence to secure food, income, safe evacuation during flooding, and recovery after floods

Results from Focus Group Discussions (FGDs) and in-depth interviews reveal that participants are concerned with several issues for maintaining livelihoods during and after floods. These include: (1) capacity to secure food, (2) income, (3) health of family members during the floods, (4) capacity to find a safe place if evacuated during floods, and (5) capacity to recover if houses are affected.

Firstly, floods occur for two to six months per year, so they often disrupt the income sources of some social groups. Poor people's livelihoods rely heavily on collecting fish and aquatic resources, and agricultural wage labor during the flood season. When a large flood event occurs, there are strong winds and giant waves that disrupt daily livelihood activities. So, if households are not confident that they will have sufficient food and income to survive during flooding, they feel that they are vulnerable to floods. Medium and better-off households reported that they are less vulnerable to floods as they have sufficient savings to use during the flood period.

A poor woman, aged 26, living in K9 hamlet, Phu Duc commune, Tam Nong district, Dong Thap province, and a second poor woman, aged 33, said that poor people worried seven to eight times more during flooding, while better-off 
households only worried two to three times more. They are concerned about a shortage of income for purchasing rice (FGD 01PD January 2010).

However, if they can access resources from family members, neighbors, and social networks, they may be confident of securing food and income during the flood season. For example, seasonal migration may provide remittances to send to their family members to help them survive during the flood season.

The president of the Thanh My Tay commune reported that there were about 5,000 seasonal migrants in this commune in 2009. Some poor migrants go to Ho Chi Minh (HCM) City to work in the construction sector, such as builders, to avoid the floods and come back to do agricultural labor in the dry season. Other migrants stay permanently in HCM city, if they find a good job. There seem to be two types of migration: push and pull. Some successful migrants send remittances to their family. For example, one man has two sons working in HCM City; they send him a remittance each month. He can live well with the floods now. However, migration is not stable for some social groups (in-depth interview on $15^{\text {th }}$ September 2010).

A poor women, aged 32, living in Phu Duc commune, said that her husband works for a construction company in HCM city as a builder. Income from laboring in HCM is more stable than working in this Phu Duc commune. Some days are off, but some days we work. The job is not secure here (in-depth interview on $11^{\text {th }}$ September 2010).

In contrast, seasonal migration provides an important opportunity for coping with floods, but it is also a challenge for some people. Some people cannot save money or even go into debt because they do not find a good job in HCM city.

A poor woman, aged 35, living in Phu Duc commune, said that during the flood season, most people in her places [residential clusters] ${ }^{[1]}$ close their houses and go to Ho Chi Minh city to work in the construction sector and work in garment factories. She indicated that:

Working in HCM city is for survival during the flood
season. My husband and I went to HMCand returned
to do agricultural labor in the dry season. Life in
HCM is also very hard. We returned without any
money. We lost networks in the village. We feel life
is more difficult than before [in-depth interview on
$12^{\text {th }}$ September 2010].

Child deaths during the flood season were cited as the key concerns of most participants in twelve FGDs. Children were recognized as the most vulnerable group, especially during large flood events. Deaths of children were not directly caused by flood-related disease, but related to drowning due to lack of supervision from caregivers. Many examples show that children drowned while their parents were doing housework, sleeping at night, and fishing on the floodplain. Children's deaths were mostly reported in the highest and moderate flood prone regions, while very few cases were mentioned in the low flood region. Importantly, most people said that child deaths were more likely to happen in households who settled in the paddy fields. Poor households, who went fishing during the floods, had to leave their children at home alone or with their brothers and sisters or relatives. Lack of supervision resulted in vulnerability to floods.

A primary teacher in Phu Duc commune, aged 41, recalled that his house floor was submerged in the 2000 flood. He had to remove the wooden floor ${ }^{[2]}$ to keep the house from being swept away by the floodwater. His family (himself, wife and little son) had to survive in the only bed for several days. They cooked, ate and slept, toileted .... on the bed. Suddenly, his son fell into the floodwater underneath the floor. Luckily he grabbed him in time. If he had not grabbed him, his son would have been swept away by the strong waves (FGD PD02).

Evacuation during floods is one of the most important indicators of living with floods at the household level. If the flood submerges homes, having a safe place to which to evacuate provides confidence to cope with floods. In the flood of 2000, many people could not move out of their homes for several days. They had to stay on the roofs of their houses when the water was rising. Their lives were at risk all the time during the flood.

A poor woman in Phu Duc commune, aged 35, said that her house was deeply submerged in the 2000 flood; all clothes were wet, while there was no rice to eat. No family members could sleep and they lost weight. Her house was located along the canal banks and was cut off by floodwaters. It was very difficult to find a safe place to evacuate to (FGD 02PD January 2010).

Recovery after floods was considered another important indicator of coping with floods. Evidence shows that the flood in 2000 destroyed and submerged thousands of homes in the MRD. If someone could recover more quickly they would be more resilient to the impact of the flood. Poor people lived in unsafe conditions (in simple houses without protective materials inside the flooded fields), which were easily destroyed by flooding and during storms.

Confidence to secure homes that would not be affected by floods such as the 2000 flood

As reported by most participants in FGDs, the flood in 2000 can be seen as the historical flood. In flood years, many homes were submerged or destroyed by flooding. The flood level in 2000 was considered as the threshold for designing housing structures by most rural households. Through field observation and FGDs with participants in three study sites, it was found that both richer households and poorer ones that resided in residential clusters were more likely to be confident that their 
houses would not be submerged or destroyed by a flood as large as the 2000 flood. This indicator reflects the threshold that rural households can cope with floods in terms of the housing sector. Two items (items 2 and 3) which formed the factor explaining the threshold were included (Table 3).

\section{Interest in learning and implementing flood-based} livelihoods during floods

As noted by Paul (1984, 1995, 1997) and Shaw (1989) floods are hazards as well as resources for development. Some people may see floods as disasters, but others consider floods as benefits (Lebel et al. 2006). The large flood event in the MRD led to significant costs to households and communities, but farmers can also benefit from the resources that the floods give to people. In particular, such floods bring abundance of aquatic resources such as fish, crabs, and snails. Many farmers rely on income from collecting fish, crabs, and snails during the flood season for maintaining livelihoods. However, poor people may not have enough financial resources to buy fishing tools (a small boat, nets, or traps), which may make them more vulnerable to food insecurity during the flood season. In some cases, they borrow informal credit for purchasing a boat and nets. However, they may incur debt during large floods that may sweep away their nets. The following in-depth interview illustrates the ways that people completely adapt to the flood season in the highest flood prone region.

A rice farmer in $\mathrm{K} 9$ hamlet, aged 45, Phu Duc commune, has one hectare of rice land. He traps fish during the flood season. He loves the flood season very much because he can earn an extra VND 200,000-300,000 per day from this off-farm activity (in-depth interview on $15^{\text {th }}$ September 2010).

Interestingly, rural people have adapted to floods using an innovative way for improving their household income in the moderate flood prone region. The golden snails have been seen as pests for rice farmers in the MRD. However, they become resources for people who can collect golden snails for maintaining livelihoods during flooding. Most poor and medium income households engage in these livelihood activities because they require less capital investment as well as labor. In particular, young couples who are poor and landless are more likely to participate in this activity for survival, while medium-income households are more likely to accumulate capital by conducting this business.

The household income of a medium-income farmer in TMT commune, aged 45, relies on rice farming (two crops) and collecting golden snails during the flood season. He said that local people are very interested in livelihood activities during the flood season. He uses a small motorboat to travel to many places in An Giang, Dong Thap, and Kien Giang provinces to collect snails. He can earn a net income of around VND 300,000 ( USD 15) per day. He can save at least VND 10.0 mil (USD 480) in a flood season, which equals the net income from 2.0 ha of rice. Mr. Luoc realized that the water season is a wonderful income season for his family and his neighbors. Fish, prawn, and duck farmers can buy low-priced snails, a cheap source of protein to feed their stock. Children and old people in his neighborhood can earn about VND 50,000 ( USD 3.5) a day to take off the snail shells for him [in-depth interview on $5^{\text {th }}$ January 2010].

Local people not only benefit from exploiting the natural fish, crabs or snails from the floodplain, but also they create new farming activities that are totally adapted to floodwaters. For example, medium and better-off farmers who have paddy land are more likely to grow Neptunia prostrate (a type of aquatic vegetable), integrate duck and fish farming systems, and cultivate prawns during the flood season. These farming activities were introduced by farmers in 2001. The activities were first tested on an individual basis and expanded to the community level. The stories that follow show that farmers are more resilient to floods by transforming flooded fields into flood-based farming practices.

A 61-year old man, living in Trung An commune, owns 3 ha of rice land. He grows two rice crops in the dry season and uses an integrated farming system during the water season. In particular, Mr. Sau raises ducks and fish in the flooded paddy fields using net fences to keep ducks and fish inside. He started to implement this system five years ago and the system is quite sustainable. He said that after harvesting the summer rice crop, he put nursery fish into the paddy fields. Fish eat rice straws, worms, and falling rice husk. Additionally, he adds ducklings and ducks into the paddy fields. Ducks also eat the remaining falling rice husk. After four months, he harvests fish, ducks, and eggs. The net benefit of these resources is much greater than the net benefit of the main rice crop. The fish and ducks make the paddy soil more fertile, so rice farmers apply less fertilizer in the next crop. This system is more resilient to the water season. Farmers can gain double benefits from the system. However, the system is not suitable for the landless and poor. It requires land and capital for investment, which the poor cannot afford (in-depth interview on January $15^{\text {th }}$ 2010).

Another man, aged 40, with nine years of schooling, lives in Bo Dau hamlet, TMT commune and owns 0.7 ha of rice land. He grows two rice crops in the dry season and raises prawn in the paddy-flooded fields in the flood season. He has adopted new flood-based prawn farming since 2007 . He uses bamboo fences and nets to keep the prawn inside the fences and uses floodwater for farming prawn. He said that the water season is good for prawn farmers like him. Although the system is very risky with the market as well as water environment, it brings enormous benefit. Compared to two rice crops, this farming practice generates greater benefits. In 2007, he earned a net benefit of VND 70 million $(\$ 3,500)$ from prawn (in-depth interview on January $\left.06^{\text {th }} 2010\right)$. 


\section{Discussion and Conclusion}

This study has identified the key characteristics of households that determine the capacity of households to cope with, adapt to, and benefit from floods. As discussed by de Vaus (2002) it is better to use multiple items to measure a multidimensional concept. Although resilience is a multidimensional concept, it can be grouped into three different components in the context of living with floods in the MRD. Three factors found by this study include: (1) the capacity of households to secure food, income, health of their family members during the flood season, safe evacuation during future extreme flood events, and recovery after extreme floods if they are affected, (2) the capacity of households to secure their homes during large floods such as the historic flood of 2000, (3) the level of interest in learning and carrying out new flood-based livelihoods during the flood season to improve their livelihood security. These three factors are consistent with general resilience theory and practices. A novel point of this study is to identify the capacity to learn from disturbance for genuine adaptation to floods. The ways that farmers use floodwater for growing prawns, fish, eels, and vegetables are very innovative and transformative.

The first factor of resilience in this study related to the degree to which households are capable of self-organization. This characteristic has been mostly accepted by resilience researchers (Klein et al. 2003, Carpenter et al. 2001, Folke 2006). However, it is difficult to translate the term "capacity for self-organization" into the real context of living with floods in the MRD. In particular, the capacity for self-organization comprises several dimensions of livelihoods with people being mostly concerned about the impacts of previous flood events. These dimensions are confidence that they have sufficient food to eat during the flood season, confidence that they do not need to borrow informal credit during the flood season and can find a safe place to evacuate to during future extreme flood events; and confidence that the health of their family members is secured.

Because the flood season often disrupts income streams of some socioeconomic groups, borrowing money from local informal credit is the common way of coping with six months of flooding. Accessing informal credit with high interest rates is the fear of most poor households during the flood season. Landless households are the most vulnerable groups from being in chronic debt with informal credit providers because they do not have land title to borrow against for formal credit to survive during the flood season. However, if households are confident that they will not borrow this type of credit, they may be able to borrow from their relatives, family members, and the banks with low interest. These sources of support are important for them to maintain their livelihoods during the flood season. Health of family members, especially children, is the most serious concern during floods. Many children died because of drowning. If households are confident that they can keep their children secure in the face of flooding, they are more likely to be resilient.

In particular, rice is the most important staple food for rural households in the MRD. If the households do not have enough rice to eat, they feel very anxious about coping with the flood season. In the developing country context, especially Southeast Asia, food sources are often at the backdoor in nearby ponds and with close neighbors and do not require access to highly developed Western-style transport and communications systems.

A medium well-off woman, aged 44, living in Phu Duc commune, said that a good neighbor used his small ferry to evacuate people, animals, and supply food to people when the large flood of 2000 submerged most houses in the village. He mobilized local resources (food and clothes) from the less affected villages to help them. She said that transportation by boat is the most effective means during the large flood season.

Rural-urban remittances may help some people to maintain their income during the flood season. But in some cases, migration does not necessarily help some households to improve their income because the living cost in Binh Duong or Ho Chi Minh City is relatively high. So, many migrants reported that they return homes without money and sometimes are in debt. As a result, they become more vulnerable to future flood events.

A poor woman in Phu Duc commune, aged 38, with nine years of schooling, said that she has lived in this village for 30 years. She originated from Cao Lanh district of Dong Thap province. She used to live by an internal canal subjected to annual flooding. Her income is mainly from fishing and collecting. However, the floods have been small in the past several years and she could not catch much fish. She decided to go to Binh Duong to work in a factory. However, the salary was not sufficient for her family to survive. She decided to return homes and her livelihood is difficult now.

The second characteristic of resilience is related to the amount of disturbance that a system can cope with, while still maintaining its function in terms of the housing sector. This characteristic has been widely accepted in recent natural hazards literature. In this study, the amount of disturbance is seen as the amount or magnitude of flood events in the MRD. The historic flood of 2000 was perceived as the most serious, destructive flood of the last century in the MRD. Thousands of homes were submerged, damaged, and swept away by the flood. Since that event, local people upgraded their house floors or raised the house foundation above the flood level. However, not all households can adjust their home to a certain level of stability because of financial barriers. The capacity to secure their homes so that they would not be affected by floods like the 2000 flood is determined by their well-being or 
capacity to cope with floods. Those who can upgrade their house are more resilient to the impacts of floods.

The third characteristic of household resilience is about their interest in learning and doing new creative things. This is consistent with the third property of resilience, namely, the capacity to transform and innovate (Folke et al. 2002, Walker et al. 2004, Marschke and Berkes 2006, Marshall and Marshall 2007). However, what are the new creative things in this context? Many farmers developed an innovative way of living with floods by exploiting the flood benefits as well as carrying out flood-based farming activities. These farming practices allow them to improve their household income and create jobs for local laborers to maintain their livelihoods during flood months. These emerging flood-based farming practices not only provide income and food security for rural households, but also help to maintain agricultural sustainability. The perception of floods transformed them from natural disasters into beneficial resources for livelihood development.

The subjective well-being approach of measuring households' resilience is used to reflect the actual capacity of households to cope with flood events. Because resilience is a multidimensional concept, the use of multiple items can help to capture a wide range of factors that contribute to households' resilience in a specific context. The use of standardized data yielded better underlying factors than the nonstandardized data in this context. While the former approach captured nine items forming three factors, the latter approach only obtained five items forming three factors (Appendix A 1). A standard factor analysis cannot deal with dichotomous variables, but the standardized data approach allowed a factor analysis to be carried out with dichotomous responses. This approach was well validated by using both SPSS and MPLUS software (Appendix A 2). By combining qualitative and quantitative analytical methods, new aspects of resilience among farmers in the MRD have been highlighted. The responses and adaptive behaviors enable some of these farmers to sustain their livelihoods during floods and recover quickly afterward.

However, the use of the subjective well-being approach to obtain the perceived capacity at the household level to cope with historical flood events may be prone to some limitations in explaining the resilience of households to future large flood events in the context of climate change. Although item 6 in Table 2 reflects the capacity to evacuate in a future extreme flood event, it does not capture all the dimensions of resilience in future large flood events. For example, with regard to the level of interest in learning and carrying out new flood-based livelihoods, this measure does not take into account future large flood events or very small flood events that may occur due to climate change, which may exceed the capacity of households. This is a key limitation of this research. Therefore, it is important for future research to integrate climate change scenarios into the questionnaires for assessing the resilience of households in the MRD.
It is also argued that the determinants of resilience may include demographic, social capital, cultural, economic, and political, aspects of the natural hazards, information, and the geographic setting of places (Gaillard 2007, Norris et al. 2008). For example, information and social networks are very vital for people in disaster prone areas to make behavioral decisions. But these factors may be variable at different scales of analysis. The social capital of households is important for accessing resources to cope with annual flood events. However, some of these factors are not included in the current measures of households' resilience to floods within the scope of this research. The current measures of households' resilience were more likely to focus on conceptualizing the concept of resilience in the real context of "living with floods" in the MRD. Some factors such as social capital are often treated as exogenous variables (Narayan and Pritchett 1997). The resilience properties obtained from the factor analysis from this research will be used as latent variables to investigate their relationships with social capital and socioeconomic variables of households in further analysis. At present, the current measures focus on the experience or perceptions of households in coping with past flood events, but do not permit interpretation of the results in the context of climate change. Further study should be carried out to improve the current measures of resilience in future flooding under predicted climate change scenarios.

Responses to this article can be read online at: http://www.ecologyandsociety.org/issues/responses. $\mathrm{php} / 5427$

\section{Acknowledgments:}

I wish to thank the Australian Agency for Aid and Development (AusAID) and the Environment Economy Program for Southeast Asia (EEPSEA), my supervisors at the Australian National University, and colleagues at An Giang University in Vietnam who supported my research.

\section{LITERATURE CITED}

Adger, W. N. 1999. Social vulnerability to climate change and extremes in coastal Vietnam. World Development 27 (2):249-269.

Adger, W. N. 2000. Social and ecological resilience: are they related? Progress in Human Geography 24(3):347-364.

Adger, W. N. 2003. Social capital, collective action, and adaptation to climate change. Economic Geography 79 (4):387-404. 
Adger, W. N., P. M. Kelly, A. Winkels, A., L. Q. Huy, and C. Locke. 2002. Migration, remittances, livelihood trajectories, and social resilience. Ambio 31(4):358-366.

An Giang Department of Statistics. 2009. Nien Giam Thong Ke An Giang (An Giang Statistics Yearbook). An Giang Department of Statistics, Long Xuyen, Vietnam.

Baek, H. S., K. U. Lee, E. J. Joo, M. Y. Lee, and K. S. Choi. 2010. Reliability and validity of the Korean version of the Connor-Davidson resilience scale. Psychiatry Investigation 7 (2):109-115.

Berkes, F., and C. S. Seixas. 2005. Building resilience in Lagoon social-ecological system: a local level perspective. Ecosystems 8:967-974.

Biggs, D., F. Miller, C. T. Hoanh, and F. Molle. 2009. The delta machine: water management in the Vietnamese Mekong Delta in historical and contemporary perspectives. Pages 203-225 in F. Molle, T. Foran, and M. Karonen, editors. Contested waterscapes in the Mekong Region. Earthscan, London, UK.

Brooks, N. 2003. Vulnerability, risk and adaptation: a conceptual framework. Tyndall Centre for Climate Change Research, University of East Angila, Norwich, UK.

Brouwer, R., A. Sonia, B. Luke, and H. Enamul. 2007. Socioeconomic Vulnerability and adaptation to environmental risk: a case study of climate change and flooding in Bangladesh. Risk Analysis 27(2):313-326.

Bruijn, K. M. D. 2004. Resilience indicators for flood risk management systems of lowland rivers. International Journal of River Basin Management 2(3):199-210.

Buckle, P. 2006. Assessing social resilience. Pages 88-103 in D. Paton, and D. Johnston, editors. Disaster resilience: an integrated approach. Charles C. Thomas, Springfield, Illinois, USA.

Can Tho University. 1995. Flood forecasting and damage reduction study in the Mekong Delta. University of Can Tho, Can Tho, Vietnam.

Carew-Reid, J. 2008. Rapid assessment of the extent and impact of sea level rise in Vietnam. Discussion Paper 1. International Center for Environmental Management (ICEM), Brisbane, Australia.

Carpenter, S., B. Walker, J. M. Anderies, and N. Abel. 2001. From metaphor to measurement: resilience of what to what? Ecosystems 4(8):765-781.

Carpenter, S. R., F. Westley, and M. G. Tunner. 2005. Surrogates for resilience of social-ecological systems. Ecosystems 8:941-944.
Colding, J., T. Elmqvist, and P. Olsson. 2003. Living with disturbance: building resilience in social-ecological systems. Pages 132-136 in F. Berkes, J. Colding, and C. Folke, editors. Navigating social-ecological systems: building resilience for complexity and change. Cambridge University Press, Cambridge, UK.

Copestake, J., and L. Camfield. 2009. Measuring subjective wellbeing in Bangladesh, Ethiopia, Peru and Thailand using personal life goal satisfaction approach. University of Bath WeD Working Paper 09/45. University of Bath/ Wellbeing in Developing Countries Research Group, Bath, UK.

Cumming, G. S., G. Barnes, S. Perz, M. Schmink, K. E. Sieving, J. Southworth, M. Binford, R. D. Holt, C. Stickler, and T. V. Holt. 2005. An exploratory framework for the empirical measurment of resilience. Ecosystems 8:975-987.

Cutter, S. L., B. J. Boruff, and W. L. Shirley. 2003. Social vulnerability to environmental hazards. Social Science Quaterly 84(2):242-261.

Dasgupta, S., L. Benoit, M. Craig, W. David, and J. Yan. 2007. The impact of sea level rise on developing countries: a comparative analysis. World Bank, Washington D.C., USA.

de Vaus, D. A. 2002. Surveys in social research. Allen and Unwin, Sydney, Australia.

Eastham, J., F. Mpelasoka, M. Mainuddin, C. Ticehurst, P. Dyce, G. Hodgson, R. Ali, and M. Kirby. 2008. Mekong River Basin water resources assessment: impacts of climate change. Commonwealth Scientific and Industrial Research Organisation (CSIRO), Canberra, Australia.

Fekete, A. 2009. Validation of a social vulnerability index in context to river-floods in Germany. Natural Hazards and Earth System Sciences 9(2):393-403.

Folke, C. 2006. Resilience: the emergence of a perspective for social-ecological systems analyses. Global Environmental Change 16:253-267.

Folke, C., F. Berkes, and J. Colding. 1998. Linking social and ecological systems for resilience and systainability. Cambridge University Press, Cambridge, UK.

Folke, C., S. Carpenter, T. Elmqvist, L. Gunderson, C. S. Holling, and B. Walker. 2002. Resilience and sustainable development: building adaptive capacity in a world of transformation. Ambio 31(5):437-440.

Gaillard, J.-C. 2007. Resilience of traditional societies in facing natural hazards. Disaster prevention and management 16(4):522-544.

Holling, C. S. 1973. Resilience and stability of ecological systems. Annual Review of Ecological Systematics 4:1-23. 
Imamura, F., and D. V. To. 1997. Flood and typhoon disasters in Viet Nam in the half century since 1950. Natural Hazards 15:71-87.

Kim, J.-O., and C. W. Mueller. 1978. Factor analysis: statistical methods and practical issues. Sage, Beverly Hills, California, USA.

Klein, R. J. T., R. J. Nicholls, and F. Thomalla. 2003. Resilience to natural hazards: how useful is this concept? Environmental Hazards 5:35-45.

Lebel, Y. L., E. Nikitina, and J. Manuta. 2006. Flood disaster risk management in Asia: an institutional and political perspective. Science and Culture 72(12):2-9.

Maguire, B., and P. Hagan. 2007. Disasters and communities: understanding social resilience. The Australian Journal of Emergency Management 22(2):16-20.

Marschke, M. J., and F. Berkes. 2006. Exploring strategies that build livelihood resilience: a case from Cambodia. Ecology and Society 11(1):42. [online] URL:http://www. ecologyandsociety.org/issues/article.php?id=1730

Marshall, N. A., and P. A. Marshall. 2007. Conceptualizing and operationalizing social resilience within commercial fisheries in Northern Australia. Ecology and Society 12(1):1. [online] URL: http://www.ecologyandsociety.org/vol12/iss1/ $\underline{\operatorname{art} 1 /}$

Mathbor, G. M. 2007. Enhancement of community preparedness for natural disasters: the role of social work in building social capital for sustainable disaster relief and management. International Social Work 50(3):357-369.

Mekong River Commission (MRC). 2002. Freshwater aquaculture in the Lower Mekong Basin. Mekong River Commission, Phnom Penh, Cambodia.

Ministry of Natural Resources and Environment. 2009. Climate change, sea level rise scenarios for Vietnam. Ministry of Natural Resources and Environment, Hanoi, Vietnam.

Narayan, D., R. Chambers, M. K. Shah, and P. Petesch. 2000. Voice of the poor: crying out for change. Oxford University Press, New York City, New York, USA.

Narayan, D., and L. Pritchett. 1997. Cents and sociability: household income and social capital in rural Tanzania. The World Bank Social Development and Development Research Group. [online] URL: www.sfu.ca/ akaraiva/e455/Cents.pdf

Nguyen, D. H., G. Robson, and E. S. George. 2003. Report on residential clusters in An Giang, Dong Thap and Long An provinces in the Mekong Delta. Adam Fforde and Associates, Melbourne, Australia.

Nguyen, V. K. 2007. Economic and social benefits of floodbased livelihoods in Vietnam's Mekong Delta: a case study in
An Giang province. EEPSEA climate change conference (Bali, Indonesia, 13-15 February 2008).

Nguyen, V. T., and L. T. Binh. 2004. Current information on inland capture fisheries in Vietnam. Vietnam Ministry of Fisheries, Hanoi, Vietnam.

Norris, F. H., S. P. Stevens, B. Pfefferbaum, K. F. Wyche, and R. L. Pfefferbaum. 2008. Community resilience as a metaphor, theory, set of capacities, and strategies for disaster readiness. American Journal of Community Psychology 41:127-150.

Paul, B. K. 1984. Perception of and agricultural adjustment to floods in Jamuna floodplain, Bangladesh. Human Ecology 12 (1):3-19.

Paul, B. K. 1995. Farmers' responses to the flood action plan (FAP) of Bangladesh: an empirical study. World Development 23(2):299-309.

Paul, B. K. 1997. Flood research in Bangladesh in retrospect and prospect: a review. Geoforum 28(2):121-131.

Pelling, M., and C. High. 2005. Understanding adaptation: what can social capital offer assessments of adaptive capacity? Global Environmental Change 15:308-319.

Quang, P. V. 2012. Map of the study sites in the Mekong Delta. Long Xuyen, Vietnam.

Reid, J. C.-. 2008. Rapid assessment of the extent and impacts of sea level rise in Vietnam. International Center for Environmental Management (ICEM), Brisbane, Australia.

Shaw, R. 1989. Living with floods in Bangladesh. Anthropology Today 5(1):11-13.

Smith, D. R., A. Gordon, K. Meadows, and K. Zwick. 2001. Livelihood diversification in Uganda: patterns and determinants of change across two rural districts. Food Policy 26(4):421-435.

Socialist Republic of Vietnam. 2004. National report on disaster reduction in Vietnam. Ministry of Agricultural and Rural Development. Hanoi, Vietnam.

Tien, D. C. 2001a. Flooded areas of the Mekong River Delta: present situations and solutions [translated from Vietnamese]. Ho Chi Minh National University, Ho Chi Minh City, Vietnam.

Tien, D. C. 2001b. Social, economic, technical, and environmental issues in the Mekong River Delta for active living with floods [translated from Vietnamese]. Ho Chi Minh National University, Ho Chi Minh City, Vietnam.

Tinh, D. Q., and P. T. Hang. 2003. Living with floods in the Mekong River Delta of Vietnam. Department of Dike Management, Flood and Storm Control, Ministry of Agriculture and Rural Development, Hanoi, Socialist Republic of Vietnam. 
Tran, P., F. Marincioni, R. Shaw, M. Sarti, and L. V. An. 2008. Flood risk management in Central Vietnam: challenges and potentials. Natural Hazards 46(1):119-138.

Tuan, L., C. T. Hoanh, F. Miller, and B. T. Sinh. 2007. Floods and salinity management in the Mekong Delta, Vietnam. Pages 15-68 in T. T. Be, B. T. Sinh, and F. Miller, editors. Challenges to sustainable development in the Mekong Delta: regional and national policy issues and research needs. The Sustainable Mekong Research Network, Bangkok, Thailand.

Wagnild, G. M., and H. M. Young. 1993. Development and psychometric evaluation of the resilience scale. Journal of nursing measurement 1(2):165-178.

Walker, B., C. S. Holling, S. R. Carpenter, and A. Kinzing. 2004. Resilience, adaptability and transformability in socialecological systems. Ecology and Society 9(2):5. [online] URL: http://www.ecologyandsociety.org/vol9/iss2/art5/

Wang, L., Z. Shi, Y. Zhang, and Z. Zhang. 2010. Psychometric properties of the 10-item Connor-Davidson resilience scale in Chinese earthquake victims. Psychiatry and Clinical Neurosciences 64:499-504.

Wassmann, R., X. H. Nguyen, C. T. Hoanh, and T. P. Tuong. 2004. Sea level rise affacting the Vietnamese Mekong delta: water elevation in the flood season and implications for rice production. Climate Change 66(1-2):89-107.

Yu, X., and J. Zhang. 2007. Factor analysis and psychometric evaluation of the Connor-Davidson resilience scale (CDRISC) with Chinese people. Social Behavior and Personality 35(1):19-30.

${ }^{[1]}$ Residential clusters are artificial permanent shelters that were built by governments to relocate poor, vulnerable people into clusters to avoid flooding. The clusters were designed for about 200-300 households in each commune in the flood prone regions of the MRD.

${ }^{[2]}$ The floor is made of wooden boards. One wooden board is $30 \mathrm{~cm}$ in width and four to five meters in length. 


\section{APPENDIX A}

1) Factor matrix of household resilience, MRD, Vietnam, $2010^{\mathrm{a}}$ (five non-standardized items)

\begin{tabular}{|c|c|c|c|c|}
\hline \multirow[t]{2}{*}{ Survey items } & \multicolumn{3}{|c|}{ Factor loadings } & \multirow[t]{2}{*}{ Communality } \\
\hline & Factor 1 & Factor 2 & Factor 3 & \\
\hline $\begin{array}{l}\text { I am confident that my house will not be } \\
\text { submerged by the highest floods in the last } \\
20 \text { years. }\end{array}$ & 0.94 & & & 0.907 \\
\hline $\begin{array}{l}\text { I am confident that my house will not } \\
\text { collapse or be swept away by the highest } \\
\text { floods in the last } 20 \text { years. }\end{array}$ & 0.93 & & & 0.901 \\
\hline $\begin{array}{l}\text { I am confident that my household has enough } \\
\text { rice to eat during the flood season. }\end{array}$ & & 0.869 & & 0.804 \\
\hline $\begin{array}{l}\text { I am confident that my household will not } \\
\text { need to borrow rice or money from informal } \\
\text { sources during the flood season. }\end{array}$ & & 0.902 & & 0.828 \\
\hline $\begin{array}{l}\text { I want to learn new farming practices to cope } \\
\text { with floods, such as fish and prawn farming. }\end{array}$ & & & 0.999 & 0.999 \\
\hline Eigenvalues & 2.33 & 1.10 & 1.00 & 4.43 \\
\hline$\%$ of variance & 46.75 & 22.00 & 20.02 & 88.77 \\
\hline
\end{tabular}

(1) Strongly disagree; (2) Disagree; (3) Neither agree or disagree; (4) Agree; (5) Strongly agree.

Selected factor having Eigenvalue greater than 1.

Select variables with factor greater than 0.3 .

Total variance is 88.77 .

2) Factor analysis in MPLUS software. MPLUS allows conducting a factor analysis using binary variables.

\section{TESTS OF MODEL FIT}

Chi-Square Test of Model Fit

$\begin{array}{lc}\text { Value } & 48.818 * \\ \text { Degrees of Freedom } & 12 \\ \text { P-Value } & 0.0000\end{array}$

\begin{tabular}{|c|c|c|c|}
\hline VAR & RIMAX I & ROTATED & LOADINGS \\
\hline & 1 & 2 & 3 \\
\hline Q4201 & 0.648 & 0.268 & 0.180 \\
\hline Q4202 0.2 & .236 & 1.129 & -0.022 \\
\hline Q4203 0.3 & .346 & 0.702 & -0.019 \\
\hline Q4204 0.9 & 0.952 & 0.157 & -0.028 \\
\hline Q4205 & 0.871 & 0.160 & -0.084 \\
\hline Q4206 & 0.356 & 0.122 & 0.183 \\
\hline Q4208 & 0.500 & 0.193 & 0.180 \\
\hline Q4209 & 0.093 & 0.012 & 0.839 \\
\hline Q420100A & A 0.083 & -0.040 & 0.789 \\
\hline
\end{tabular}

